\title{
Front Matter: Volume 7775
}

, "Front Matter: Volume 7775," Proc. SPIE 7775, Liquid Crystals XIV, 777501 (1 September 2010); doi: 10.1117/12.876876

Event: SPIE Photonic Devices + Applications, 2010, San Diego, California, SPIE. United States 


\section{PROCEEDINGS OF SPIE}

\section{Liquid Crystals XIV}

lam Choon Khoo

Editor

1-2 and 4 August 2010

San Diego, California, United States

Sponsored and Published by

SPIE

Volume 7775

Proceedings of SPIE, 0277-786X, v. 7775

SPIE is an international society advancing an interdisciplinary approach to the science and application of light. 
The papers included in this volume were part of the technical conference cited on the cover and title page. Papers were selected and subject to review by the editors and conference program committee. Some conference presentations may not be available for publication. The papers published in these proceedings reflect the work and thoughts of the authors and are published herein as submitted. The publisher is not responsible for the validity of the information or for any outcomes resulting from reliance thereon.

Please use the following format to cite material from this book:

Author(s), "Title of Paper," in Liquid Crystals XIV, edited by lam Choon Khoo, Proceedings of SPIE Vol. 7775 (SPIE, Bellingham, WA, 2010) Article CID Number.

ISSN 0277-786X

ISBN 9780819482716

Published by

SPIE

P.O. Box 10, Bellingham, Washington 98227-0010 USA

Telephone +1 3606763290 (Pacific Time) · Fax +1 3606471445

SPIE.org

Copyright (c) 2010, Society of Photo-Optical Instrumentation Engineers

Copying of material in this book for internal or personal use, or for the internal or personal use of specific clients, beyond the fair use provisions granted by the U.S. Copyright Law is authorized by SPIE subject to payment of copying fees. The Transactional Reporting Service base fee for this volume is $\$ 18.00$ per article (or portion thereof), which should be paid directly to the Copyright Clearance Center (CCC), 222 Rosewood Drive, Danvers, MA 01923. Payment may also be made electronically through CCC Online at copyright.com. Other copying for republication, resale, advertising or promotion, or any form of systematic or multiple reproduction of any material in this book is prohibited except with permission in writing from the publisher. The CCC fee code is 0277-786X/10/\$18.00.

Printed in the United States of America.

Publication of record for individual papers is online in the SPIE Digital Library.

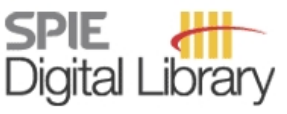

SPIEDigitalLibrary.org

Paper Numbering: Proceedings of SPIE follow an e-First publication model, with papers published first online and then in print and on CD-ROM. Papers are published as they are submitted and meet publication criteria. A unique, consistent, permanent citation identifier (CID) number is assigned to each article at the time of the first publication. Utilization of CIDs allows articles to be fully citable as soon they are published online, and connects the same identifier to all online, print, and electronic versions of the publication. SPIE uses a six-digit CID article numbering system in which:

- The first four digits correspond to the SPIE volume number.

- The last two digits indicate publication order within the volume using a Base 36 numbering system employing both numerals and letters. These two-number sets start with 00, 01, 02, 03, 04 , $05,06,07,08,09,0 A, 0 B \ldots$. OZ, followed by 10-1Z, 20-2Z, etc.

The CID number appears on each page of the manuscript. The complete citation is used on the first page, and an abbreviated version on subsequent pages. Numbers in the index correspond to the last two digits of the six-digit CID number. 


\section{Contents}

vii Conference Committee

\section{SESSION 1 NOVEL OPTICAL AND ELECTRO-OPTICAL EFFECTS}

777502 Electrically reconfigurable optical metamaterials based on orientationally ordered dispersions of metal nano-rods in dielectric fluids (Invited Paper) [7775-01]

A. B. Golovin, J. Xiang, Kent State Univ. (United States); Y. A. Nastishin, Kent State Univ. (United States) and Institute of Physical Optics (Ukraine); O. D. Lavrentovich, Kent State Univ. (United States)

777504 Holographic projection based on tapered lasers and nematic liquid crystal on silicon devices (Invited Paper) [7775-03]

N. Collings, Univ. of Cambridge (United Kingdom); M. Reufer, OSRAM Opto Semiconductors GmbH (Germany); R. V. Penty, Univ. of Cambridge (United Kingdom); B. Sumpf, Ferdinand-Braun-Institut für Höchstfrequenztechnik (Germany); M. Safer, FISBA OPTIK AG (Switzerland); D. P. Chu, W. A. Crossland, Univ. of Cambridge (United Kingdom)

777505 Self-phase modulation in azo-dye-doped liquid crystal films (Invited Paper) [7775-04] A. Y.-G. Fuh, C.-W. Chu, H.-C. Lin, H.-C. Jau, M.-S. Li, National Cheng Kung Univ. (Taiwan)

\section{SESSION 2 NANO-, ORGANIC-INORGANIC LIQUID CRYSTALS}

777506 The aggregation structures of la3d and Im3m cubic phases formed by rod-shaped mesogens ANBC and BABH (Invited Paper) [7775-05]

S. Kutsumizu, Gifu Univ. (Japan); K. Saito, Univ. of Tsukuba (Japan)

777509 Symmetry and stimulus response of chiral smectic liquid-crystalline elastomers (Invited Paper) [7775-08]

K. Hiraoka, T. Tashiro, M. Kobayashi, R. Kazama, W. Sagano, Tokyo Polytechnic Univ. (Japan)

\section{SESSION 3 FIELD-INDUCED EFFECTS AND DEVICES}

7775 0A Photoinduced reorientation of dye-doped liquid crystals and its application to microoptical elements for self-emitting devices (Invited Paper) [7775-09]

M. Kinoshita, T. Kobayashi, K. Takano, Y. Nam, T. Ikeda, Tokyo Institute of Technology (Japan)

7775 OC Alignment and electrooptic effects in nanoparticle-doped nematic liquid crystals [7775-11] B. Kinkead, Univ. of Manitoba (Canada); M. Urbanski, Univ. of Paderborn (Germany); H. Qi, Univ. of Manitoba (Canada); H.-S. Kitzerow, Univ. of Paderborn (Germany); T. Hegmann, Univ. of Manitoba (Canada) 
7775 OF Optical trapping in liquid crystals (Invited Paper) [7775-14]

F. Simoni, L. Lucchetti, L. Criante, F. Bracalente, F. Aieta, Univ. Politecnica delle Marche (Italy)

7775 OG Photoswitchable gas permeation membranes based on azobenzene-doped liquid crystals II. Permeation-switching characterization under variable volume and variable pressure conditions (Invited Paper) [7775-15]

E. Głowacki, K. Hunt, D. Abud, K. L. Marshall, Univ. of Rochester (United States)

$7775 \mathrm{OH} \quad$ Blue phases as templates for 3D colloidal photonic crystals (Invited Paper) [7775-16]

S. Zumer, Univ. of Ljubljana (Slovenia), Jozef Stefan Institute (Slovenia), and Ctr. of Excellence NAMASTE (Slovenia); M. Ravnik, Univ. of Oxford (United Kingdom); T. Porenta, Univ. of Ljubljana (Slovenia); G. P. Alexander, Univ. of Pennsylvania (United States); J. M. Yeomans, Univ. of Oxford (United Kingdom)

7775 0J Dynamic gratings in a chiral nematic liquid crystal (Invited Paper) [7775-18] A. G. Iljin, Institute of Physics (Ukraine); P. P. Salo, National Taras Shevchenko Univ. of Kyiv (Ukraine); A. G. Tereshchenko, Institute of Physics (Ukraine)

7775 OK Field-, temperature-, and anchoring-induced inhomogeneous index distribution of a nano-dispersed nematic liquid crystal near the Freedericksz transition: Monte Carlo studies (Invited Paper) [7775-13]

G. Pawlik, W. Walasik, A. C. Mitus, Wroclaw Univ. of Technology (Poland); I. C. Khoo, The Pennsylvania State Univ. (United States)

\section{SESSION 5 ADVANCES IN LIQUID CRYSTALS STUDIES}

7775 OM Droplet manipulation on a liquid crystal and polymer composite film (Invited Paper) [7775-20]

Y.-H. Lin, Y.-S. Tsou, T.-Y. Chu, J.-L. Chen, National Chiao Tung Univ. (Taiwan)

7775 ON Main chain liquid crystalline polytriazoles with aggregation-induced emission characteristics: click polymerization, mesomorphic packing, and solid state emission (Invited Paper) [7775-21]

W. Z. Yuan, Hong Kong Univ. of Science and Technology (Hong Kong, China); Z. Q. Yu, Shenzhen Univ. (China); J. W. Y. Lam, C. K. W. Jim, Hong Kong Univ. of Science and Technology (Hong Kong, China); B. Z. Z. Tang, Hong Kong Univ. of Science and Technology (Hong Kong, China) and Zhejiang Univ. (China)

777500 Synthesis and physical properties of ferrocene derivatives XXIV: structural study of liquid crystalline mono-substituted ferrocene derivatives (Invited Paper) [7775-22] N. Nakamura, Ritsumeikan Univ. (Japan); K. Hiro, Toyobo Co., Ltd. (Japan); K. Uno, Ritsumeikan Univ. (Japan)

7775 OR Electro-optical properties and possible applications of bent-core liquid crystals (Invited Paper) [7775-25]

A. Jákli, Kent State Univ. (United States) 
7775 OS Well aligned half-V ferroelectric liquid crystal in asymmetrical surface polarity controlled alignment cells (Invited Paper) [7775-26]

H.-M. P. Chen, C.-W. Lin, National Chiao Tung Univ. (Taiwan)

7775 OU The principles of laser beam control with polarization gratings introduced as diffractive waveplates (Invited Paper) [7775-28]

S. R. Nersisyan, N. V. Tabiryan, BEAM Engineering for Advanced Measurements Co. (United States); D. M. Steeves, B. R. Kimball, Army Natick Soldier Research, Development and Engineering Ctr. (United States)

SESSION 7 BLUE PHASE, BISTABILITY, AND CHIRAL LC

7775 OW Propagation of nematicons in unbiased configurations: spiraling solitons (Invited Paper) [7775-30]

J. Beeckman, K. Neyts, A. Madani, Univ. Gent (Belgium); M. Haelterman, P. Henneaux, Univ. Libre de Bruxelles (Belgium); P. J. M. Vanbrabant, Univ. Gent (Belgium)

7775 OX Slow-light birefringence and high precision polarization interferometry in liquid crystal light-valves (Invited Paper) [7775-31]

S. Residori, U. Bortolozzo, Institut Non Linéaire, CNRS, Univ. de Nice Sophia Antipolis (France); J.-P. Huignard, Jphopto (France)

7775 OY Emerging blue phase liquid crystal displays (Invited Paper) [7775-33]

L. Rao, Z. Ge, S.-T. Wu, The College of Optics and Photonics, Univ. of Central Florida (United States)

$77750 Z$ Non-symmetric broadening of the reflection notch in polymer stabilized cholesteric liquid crystals [7775-34]

L. V. Natarajan, SAIC (United States); J. R. Voss, Air Force Research Lab. (United States);

V. P. Tondiglia, SAIC (United States); D.-K. Yang, Liquid Crystal Institute (United States);

T. J. White, T. J. Bunning, Air Force Research Lab. (United States)

SESSION 8 NONLINEAR, PHOTOREFRACTIVE, AND ELECTRO-OPTICS

$777510 \quad$ Nonlinear switching of near infrared light in liquid crystal on silicon channel waveguides (Invited Paper) [7775-35]

A. d'Alessandro, Univ. degli Studi di Roma La Sapienza (Italy) and Istituto per la Microelettronica e Microsistemi, CNR (Italy); R. Asquini, M. Trotta, Univ. degli Studi di Roma La Sapienza (Italy); R. Beccherelli, Istituto per la Microelettronica e Microsistemi, CNR (Italy)

POSTER SESSION

$777517 \quad 128 \times 128$ elements liquid crystal cylindrical lens array with electrically tunable focal length [7775-40]

H. Li, K. Liu, C. Zhu, X. Zhang, C. Xie, T. Zhang, X. Shen, Huazhong Univ. of Science and Technology (China) 
777519 Full-field TN-LCSLM phase modulation characterization using digital holography [7775-42]

K. Dev, V. R. Singh, A. Asundi, Nanyang Technological Univ. (Singapore)

$77751 \mathrm{E} \quad$ Femtosecond optical Kerr gating using nonlinear photonic crystal fiber [7775-51]

Q. Xu, K. Shi, Z. Liu, The Pennsylvania State Univ. (United States)

Author Index 


\title{
Conference Committee
}

\author{
Symposium Chairs
}

Zakya H. Kafafi, National Science Foundation (United States)

Conference Chair

Iam Choon Khoo, The Pennsylvania State University (United States)

Program Committee

Timothy J. Bunning, Air Force Research Laboratory (United States)

Shaw H. Chen, University of Rochester (United States)

Neil Collings, University of Cambridge (United Kingdom)

Jean-Pierre Huignard, Thales Research \& Technology (France)

Tomiki Ikeda, Tokyo Institute of Technology (Japan)

Oleg D. Lavrentovich, Kent State University (United States)

Francesco F. Simoni, Università Politecnica delle Marche (Italy)

David M. Walba, University of Colorado at Boulder (United States)

Session Chairs

1 Novel Optical and Electro-Optical Effects

Iam Choon Khoo, The Pennsylvania State University (United States)

2 Nano-, Organic-Inorganic Liquid Crystals

Kenneth L. Marshall, University of Rochester (United States)

3 Field-Induced Effects and Devices

Francesco F. Simoni, Università Politecnica delle Marche (Italy)

4 Optical Manipulation

Neil Collings, University of Cambridge (United Kingdom)

$5 \quad$ Advances in Liquid Crystals Studies

Iam Choon Khoo, The Pennsylvania State University (United States)

6 Polarization Grating, Electro-Optics

Kenneth L. Marshall, University of Rochester (United States)

$7 \quad$ Blue Phase, Bistability, and Chiral LC

Neil Collings, University of Cambridge (United Kingdom) 
8 Nonlinear, Photorefractive, and Electro-Optics

Timothy J. Bunning, Air Force Research Laboratory (United States) 